Portland State University

PDXScholar

Engineering and Technology Management

Faculty Publications and Presentations

8-2-2015

\title{
Managing Technology Push through Marketing Testbeds: The Case of the Hi-Tech Center in Vienna, Austria
}

Rainer Hasenauer

Hi-Tech Center, Vienna, Austria

Charles M. Weber

Portland State University, webercm@pdx.edu

Peter Filo

University of Economics, Bratislava, Slovakia

Jozef Orgonáš

University of Economics, Bratislava, Slovakia

Follow this and additional works at: https://pdxscholar.library.pdx.edu/etm_fac

Part of the Operations Research, Systems Engineering and Industrial Engineering Commons Let us know how access to this document benefits you.

\section{Citation Details}

Hasenauer, R., Weber, C., Filo, P., \& Orgonas, J. (2015). Managing technology push through marketing testbeds: The case of the Hi Tech Center in Vienna, Austria. In 2015 Portland International Conference on Management of Engineering and Technology (PICMET) (pp. 99-126). IEEE.

This Presentation is brought to you for free and open access. It has been accepted for inclusion in Engineering and Technology Management Faculty Publications and Presentations by an authorized administrator of PDXScholar. Please contact us if we can make this document more accessible: pdxscholar@pdx.edu. 


\title{
Managing Technology Push through Marketing Testbeds: The Case of the Hi-Tech Center in Vienna, Austria
}

\author{
Rainer Hasenauer, Hi-Tech Center, Vienna, Austria \\ Charles Weber, Portland State University, USA \\ Peter Filo, University of Economics, Bratislava, Slovakia \\ Jozef Orgonáš University of Economics, Bratislava, Slovakia
}

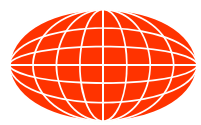

PICMET '15
August 2-6, 2015

Portland Hilton

Portland, Oregon, USA

\section{Abstract}

The 'technology push' approach to technology development rests on the assumption that if you make it, they will come. This assumption carries significant market risk. The technology may miss its intended market window, or the market that was anticipated at the inception of technology development no longer exists at the time of market release.

This paper discusses how the Hi-Tech Center in Vienna, Austria, a multi-national collaborative effort between industry and universities in Central Europe, helps its clients manage technology push by deploying the marketing testbed approach. After identifying lead users for a client's technology, it characterizes and determines optimal market entry dates and windows of opportunity; readiness for and resistance to adoption; technology acceptance and marketability; and best practices for market entry.

The Hi-Tech Center learned the following overarching lesson from engaging with six clients in six different industries: marketing testbeds comprise an effective toolkit for managing technology push, primarily because they act as a link between the technology readiness level and the market readiness level. Thus they provide early insight into the customer's willingness to pay, the degree of fit between key features of the technology and marketability criteria, and, by extension, potential return on investment. 


\section{Acknowledgements}

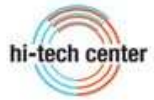

N00092 ETC Projekt SR - AT

HITECHZentrum in der grenzüberschreitenden Region

- The authors would like to thank the Hi-Tech Center in Vienna, Austria and six anonymous firms within Central Europe for sharing data that contributed to this paper.

- The Hi-Tech Center is a multi-national, multi-regional industryuniversity partnership.

- It is funded by the European Union's fund for regional development and by various local government agencies.

- Hi-Tech Center members include the Technical University of Vienna; the Economics University of Bratislava and Vienna University of Economics and Business.

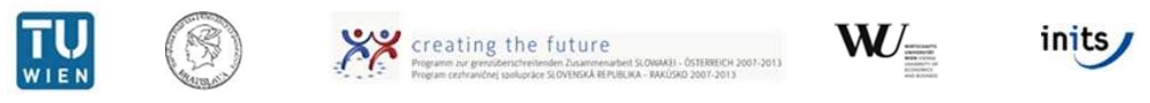

\section{Outline}

- Technology Push versus Market Pull

- Technology Readiness versus Market Readiness

- The Hi-Tech Center in Vienna, Austria

- Marketing Testbeds (MTBs)

- Evidence from Hi-Tech Center

- Data from 26 companies

- Six completed projects in six different industries

- Lessons Learned

- Future Applications

- Summary 


\section{The Economics of Innovation: Market Pull versus Technology Push}

\section{Market Pull}

Technology

Product

Market

Progress, Time

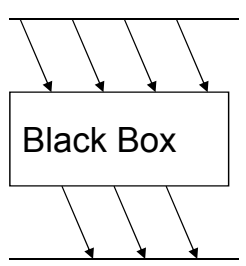

"Listen to your customers!"

$\sim 70 \%$ of studies
Technology Push

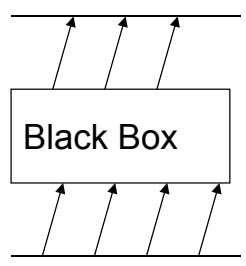

"If we make it, they will come!" $\sim 30 \%$ of studies

\section{The Challenges of Technology Push}

- If we make it, will they really come?

- We have the technology! Will they really need it?

- For what could they use our technology?

- Who are 'they', anyway?

- Significant market risk!

- Technology may miss its intended market window.

- Anticipated market may no longer exist at time of release. 
Key

Questions

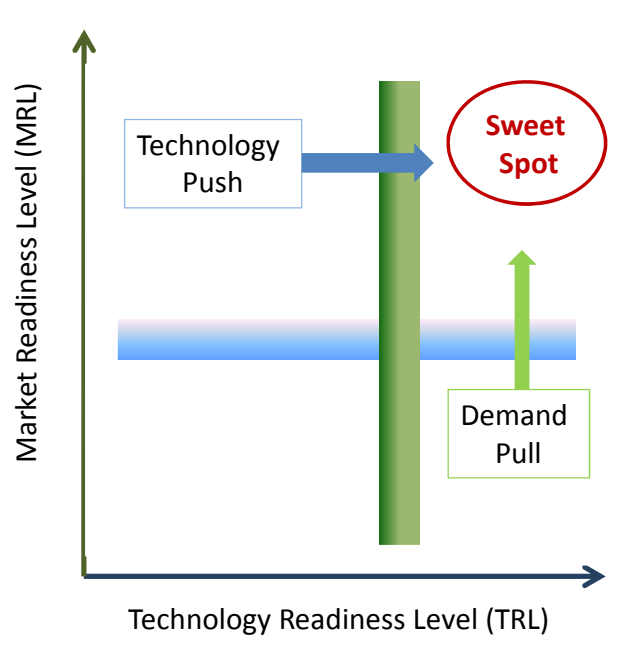

- Is the market ready for the technology?

- Is the technology ready for the market?

\section{Readiness Levels [1]}

- TRL - Technology Readiness Level

- expresses the degree of a technology

- to be used safely

- by intended and educated users

- in the envisaged commercial (market)

- or non-commercial user environment.

- MRL - Market Readiness level

- measures the maturity of a given need

- in the market considering

- the potential obstacles. 
Technology Readiness Level (TRL)

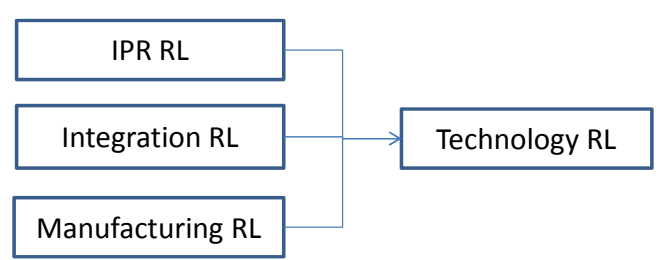

- Consists of three components (see Appendix A \& B):

- Intellectual property readiness

- Has IP been protected?

- Does the firm have the right to operate without restrictions?

- Integration readiness

- Can technologies be integrated?

- Manufacturing readiness

- Can product be manufactured?

\title{
Stages of Technology Readiness [2]-[4]
}

\author{
Level Technology Readiness \\ 1 Fundamental research \\ 2 Applied research \\ 3 Research to prove feasibility \\ 4 Laboratory demonstration \\ 5 Technology development \\ 6 Whole system field demonstration \\ 7 Industrial prototype \\ 8 Product Industrialization \\ 9 Market / sales certification
}

- Measurement of readiness level is done by checking if the criteria used to describe the level are fulfilled. 
Market

Readiness

Level (MRL)

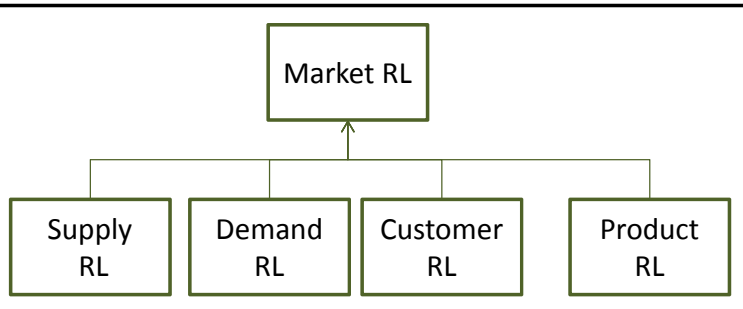

- Consists of four components:

- Supply readiness

- To what degree are competitors' products available?

- Demand readiness

- What is the demand for the product?

- Customer readiness

- Is the customer ready to use and adopt the product?

- Product readiness

- Is the product ready for widespread use?

\section{Stages of Market Readiness [5], [6]}

Level Market Readiness

1 Unsatisfied needs have been identified

2 Identification of the potential business opportunities

3 System analysis and general environment analyzed

$4 \quad$ Market research

$5 \quad$ Target defined

6 Industry analysis

7 Competitors analysis and positioning

8 Value proposition defined

9 Product/service defined

10 Business model defined coherently*

- Measurement of readiness level is done by checking if the criteria used to describe the level are fulfilled.

*Added by KIC InnoEnergy (see [7], p. 20) 


\section{The Hi-Tech Center \\ ( www.hitechcentrum.eu )}

- Multi-national collaborative effort between local industry and universities in Central Europe

- Directly deals with issues of technology push

- Funded by EU Regional Development Fund and local governments

- Provides the following services for regional startup firms and firms with high tech products:

- Market research services

- Preparation of marketing strategies

- Support for high tech start-up companies

- Specific market research tasks and business development

\section{The Hi-Tech Center's Approach: The Marketing Testbed (MTB)}

- A service for technology-driven firms

- Finds and characterizes markets for emerging technologies

- Measures market readiness and technology readiness

- Helps companies manage technology push

"This activity addresses the need of technology companies to validate the need for their product and its business case." [8]

- MTB is practiced in telecom industry (S. Korea \& Israel)

- Novelty in most high tech industries 


\section{Marketing Testbed (ctd.)}

- Analogous to but different from usability testbed

- Focuses on marketing tools (Appendix C)

- Marketing mix

$-4 \mathrm{Ps}$

- Product: technology- \& product acceptance

- Pricing/willingness to pay

- Promotion: Marketing communication

- Place: Sales and distribution channels

\section{Objectives of Testbed Approach}

- Characterize and determine

- Identify lead users [9]

- Market entry date and window of opportunity [10]

- Readiness for and resistance to adoption [11]

- Technology acceptance and marketability [12]

- Market entry for high tech innovation [10]-[13]

- Marketing management methods for high tech products [10]-[14] 


\section{Market Research and Analysis Methods}

- Problem-centered interview (PCI) [15]

- Analytical hierarchy process (AHP) [16], [17]

- MCDM (multi criteria decision making) [18]

- especially in B2B markets

- Technology acceptance

- by perceived usefulness (PU)

- and perceived ease of use (PEoU)

\section{Technology Push/Market Entry Projects}

(2013-2014)

\begin{tabular}{|c|c|}
\hline$\underline{I D}$ & Innovation \\
\hline $\bar{A}$ & $\overline{\text { Gesture controlled } \mathrm{mmi}}$ \\
\hline B & Technical simulation \\
\hline C & $\begin{array}{l}\text { Atmospheric nitrogen } \\
\text { deposition collector }\end{array}$ \\
\hline D & Aerosol jet-printing \\
\hline$E$ & Selective Laser Melting \\
\hline $\mathrm{F}$ & Sensors for mobile robots \\
\hline G & Health CCPM \\
\hline $\mathrm{H}$ & Safety Robot \\
\hline I & $\begin{array}{l}\text { Atmospheric plasma } \\
\text { for wood surface energy }\end{array}$ \\
\hline J & Phase change material \\
\hline K & Flame retardant rubber \\
\hline $\mathrm{L}$ & Magic lens augmented reality \\
\hline M & Bone diagnostics \\
\hline
\end{tabular}

$\begin{array}{ll}\frac{\text { Entry }}{2014} & \text { Industry } \\ 2014 & \text { scanner } \\ 2014 & \text { seftware } \\ & \text { sensor } \\ 2014 & \text { 3d printing } \\ 2014 & \text { 3d printing } \\ 2014 & \text { sensor } \\ 2013 & \text { robotics } \\ 2013 & \text { robotics } \\ 2013 & \text { material science } \\ & \\ 2013 & \text { building construction } \\ 2013 & \text { material science } \\ 2013 & \text { software } \\ 2013 & \text { medical diagnosis }\end{array}$




\section{Technology Push/Market Entry Projects}

(2011-2012)

\begin{tabular}{|c|c|c|c|}
\hline$\underline{I D}$ & Innovation & Entry & $\underline{\text { Industry }}$ \\
\hline $\mathrm{N}$ & $\begin{array}{l}\text { Continuous Non-Invasive } \\
\text { Blood-Pressure Measurement }\end{array}$ & 2012 & medical diagno \\
\hline $\mathrm{O}$ & 'Watch dog' for semiconductor & 2012 & software \\
\hline$P$ & Containment & 2012 & building cons \\
\hline $\mathrm{R}$ & Lab on chip diagnostics & 2012 & software \\
\hline S & Vibrational acoustic analysis & 2012 & medical dic \\
\hline $\mathrm{T}$ & Smart bottling plant & 2011 & machine col \\
\hline$U$ & Bright red systems & 2011 & scanner \\
\hline $\mathrm{V}$ & $\begin{array}{l}\text { mmi pressure and } \\
\text { temperature sensors }\end{array}$ & 2011 & sensor \\
\hline W & Bionic surface & 2011 & material science \\
\hline$X$ & Cellular materials & 2011 & material science \\
\hline (y & V-REDOX & 2011 & energy storage \\
\hline & Diamond-like carbon & 2011 & material science \\
\hline
\end{tabular}

\section{Readiness of 26 Technology Push Projects} (2014)

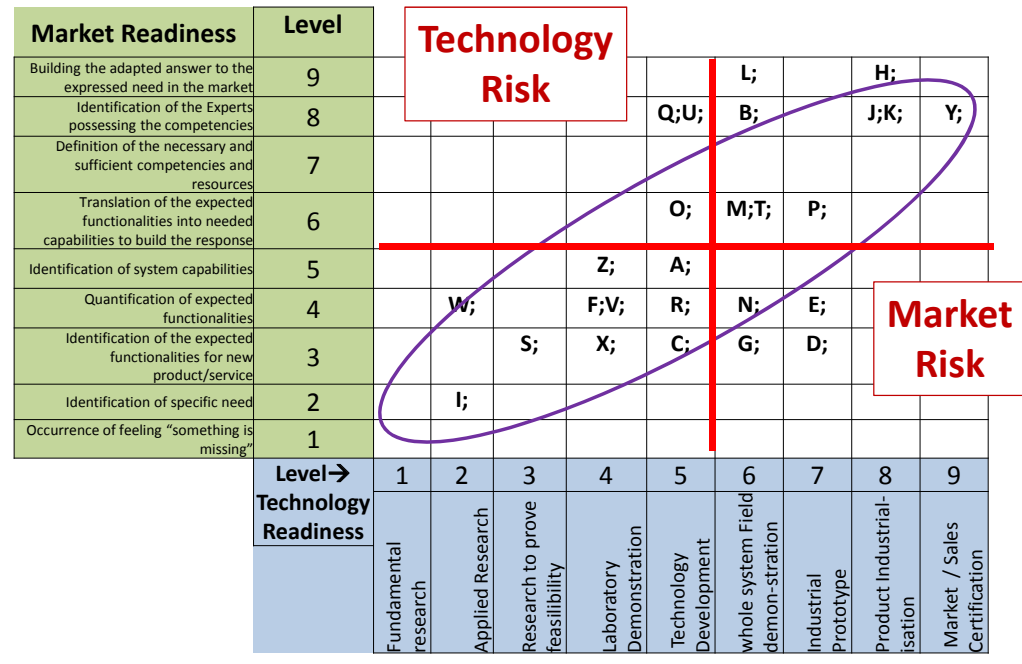

- Please see Appendix D for more detailed scores. 


\section{Lessons Learned \#1:}

\section{Stay on the Diagonal!}

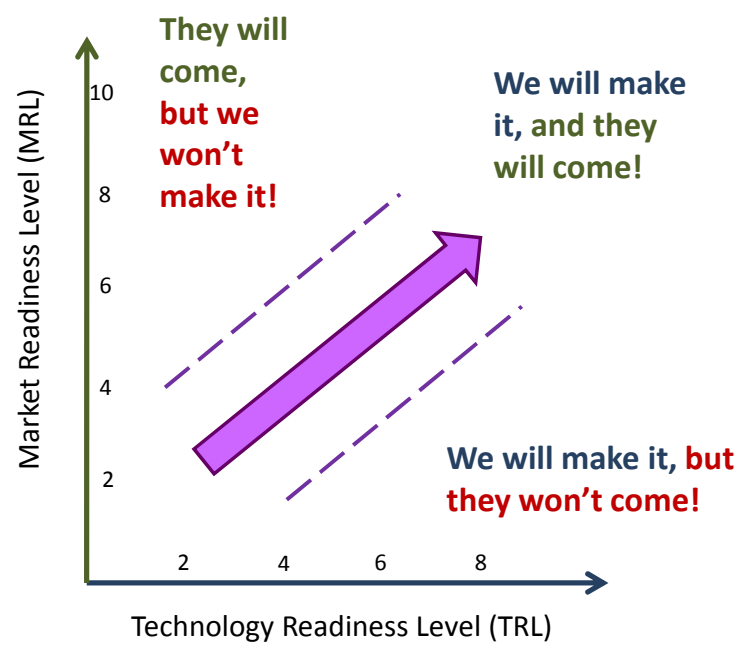

- Concurrent, step-by-step market and technology development places the right product into the right market window at the right time.

Six Selected MTB Cases for Tech. Push

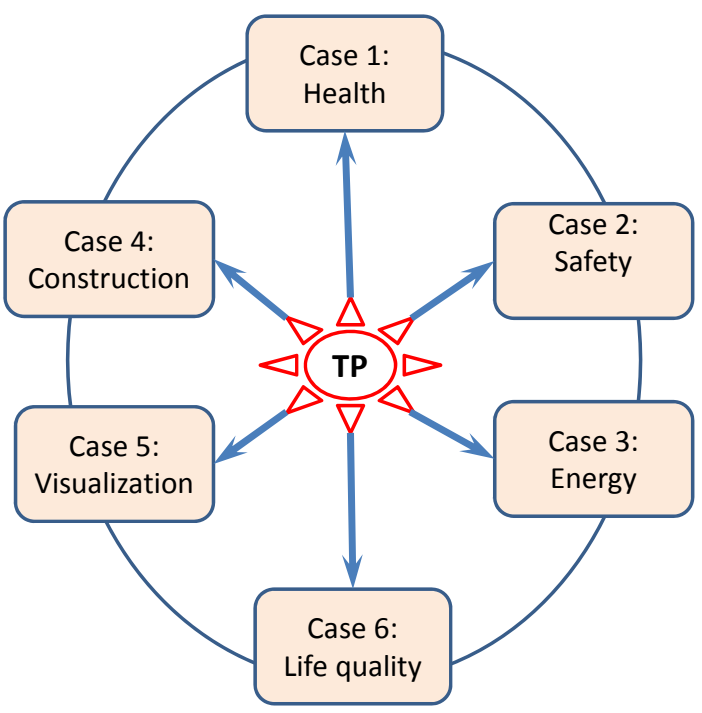

- $A l l$ in $B 2 B$ markets

- Marketing testbed process complete

- For case 4 $M R L=2$; $\mathrm{TRL}=3$.

- For all others, $\mathrm{TRL} \geq 7$; $M R L \geq 7$. 


\section{Technology Push-Case M1: CCPM Robot for Rehabilitation}

- Technology: Continuous compliant passive motion (CCPM)

- For medical applications

- Initial application: rehabilitation after shoulder surgery

- MTB Activity:

- Intensive market research

- Analysis of competitors and technology acceptance

- First clinical study was successful.

- Unique selling proposition (USP):

- High compliance of the robot

- towards patients' pain expectation

- (Robot uses efficient acceleration sensors.)

- Target Market: orthopedic hospitals / doctors

\section{Technology Push-Case 2: Safety/Security Robot}

- Unmanned guided vehicle

- Dedicated to hazardous missions

- Waterproof, 'ruggedized' and ATEX certified

- Intuitive control system and multipurpose interfaces

- Key area of application: Coal mining missions

- Communication in real time is critical.

- MTB focused on evaluation of

- perceived usefulness

- perceived ease of use under human guidance

- robot-robot cooperation in open air 


\section{Technology Push-Case 3: Building Insulation}

- Thermal insulation using phase change material (PCM)

- based on BASF Micronal ${ }^{\circledR}$

- Application:

- Intelligent temperature management for buildings

- Significant energy savings

- MTB focused on value chain

- from building physicists, architects, civil engineers, energy planner to building owner

- Willingness to pay analysis showed clear preferences

- Technology acceptance analysis performed

- Usability requirements tested

- Industrial standards evaluation showed market resistance

\section{Technology Push-Case 4: Plasma Glue}

- Technology replaces glue by surface energy

- Influences surface energy of wood

- by atmospheric plasma (Dielectric Barrier Discharge DBD)

- Improves adhesive forces by a factor of 1.5 to 2

- Reduces quantity of glue required by up to $50 \%$

- Speeds up of physical drying by a factor of 2

- The effects vary with type of wood, wood fiber orientation, impregnation and type of glue.

- For some combinations no effect was detectable.

- Application: multi-layered boards for construction.

- MTB:

- Identified early customers;

- Technical stress tests for a variety materials, voltages and levels of humidity

- Further experimental evidence is needed. 


\section{Technology Push-Case 5: Magic Lens}

- Tablet application

- recognizes objects

- in a live camera image

- and adds additional information

- using augmented reality

- Communicates features of a product more effectively.

- Use cases: trade shows, sales talks and show rooms

- Example: "Most important, USP is a process, happens inside the product. Magic lens visualizes in real time."

- Convincing by understanding generates trust

- MTB process identified new customers and tested how sophisticated they were.

- Further details see http://www.magiclensapp.com

\section{Technology Push-Case 6: V-REDOX}

- Vanadium sulfate reduction oxidation (V-REDOX)

- Flow battery technology enabling and

- Suited for stationary Remote Area Power Supply (RAPS)

- Can be coupled with photovoltaics and wind power

- Low self discharge, high longevity of electrolyte, safe.

- Improves quality of human life in remote areas.

- MTB analyzed

- Technology acceptance and fulfillment of marketability criteria

- Volatility of raw material prices of electrolyte

- Business model variants 


\section{Lessons Learned-\#2: MTB Keeps you on the diagonal!}

- With MTB, they will come, if you will make it.

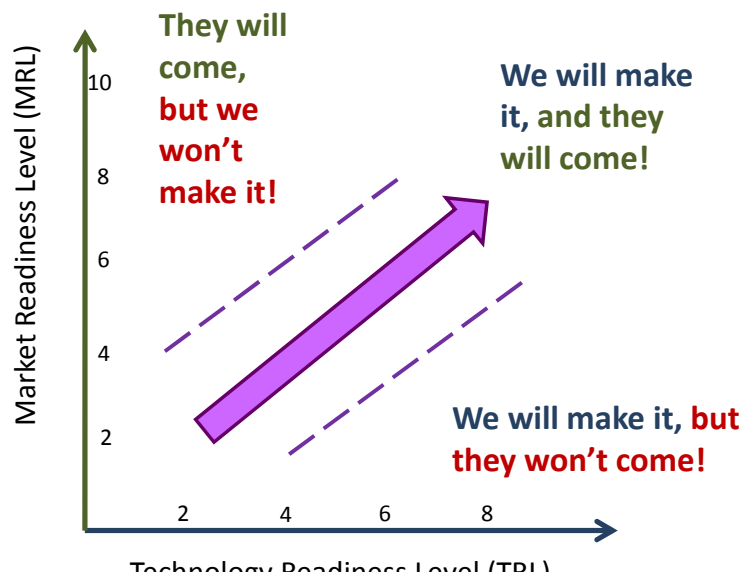

Technology Readiness Level (TRL)

\section{Lesson Learned-\#3:}

\section{About the Marketing Testbed Process}

1. Most frequent challenge: given a technology $=>$ where is the market?

2. Understand technology prototype and early customer demand in the customers' language

3. Characterize the problem solving capacity for Problem $X$

4. Identify potential users who have Problem X

5. Explore their technology acceptance, their marketability requirements (incl. standards), WTP and their readiness to assimilate new technology [13]

6. Act as a "translator" from customers demand into technology supply. (Multidisciplinary communication/ Buying Center)

7. Average manpower for MTB job: 3 pers. @ 160 hrs./pers. 


\section{Lessons Learned-\#4: \\ About Technology Push in B2B Markets}

- Overall Readiness is an integrated concept

- Consists of Technology -, Market - and Societal- Readiness.

- Interface between push and pull

- Requires deep mutual understanding

- Of supply and demand at the technology frontier.

- Pricing strategy:

- Matching solution space with benefit space (iterative process)

- Translate benefits into monetary terms

- Having reached TRL=4,

- Start approaching latent/emergent markets

- Develop valid understanding of their technological problems.

- Behind each bottleneck is a latent market. [18]

\section{Lessons Learned-\#5: Return on Investment}

- ROI depends on Time to Market, customer's WTP and sustainable technology leadership.

- Technology Push ROI-risk is reduced by staying concurrently in alignment with latent/emerging markets,

- Look out for competitors 


\section{Lessons Learned-\#5: Return on Investment (ctd.)}

- Return on investment is a tradeoff!

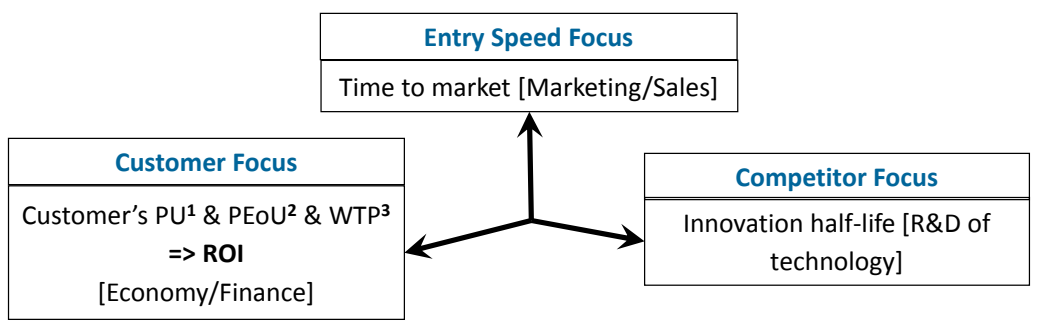

\section{Future Plans}

- CCPM: European quality certificate and multi-site testing

- Safety Robot: Conquer new markets

- Building Insulation:

- Conquer European markets

- Export to USA.

- Plasma: More applications testing (1 year +)

- Magic Lens: Export to USA; found US subsidiary.

- V-Redox: Introduction to US Market (buffer batteries)

- Hi-Tech Center plans to

- Become a private company that specializes in MTB service

- Collaborate with incubators and venture funds 


\section{Summary}

- Technology-driven firms develop highly innovative technology that is looking for new markets

- Marketing testbed studies identify and characterize these markets

- They bridge the gap between suppliers/innovators and users/customers

- Technology enters more markets.

- Time to market is reduced.

- Flop risk is reduced.

- This paper has shown that the MTB approach to managing technology push is applicable to many technologies made by firms in many industries.

\section{$Q \& A$}

Thank you for your attention!

Additional non-confidential data for MTB studies on the technologies under study are available upon request. Some are presented in the appendixes. 


\section{References (1)}

[1] D. Dent and B. Pettit, "Technology and Market Readiness Levels.," (White Paper)Dent Associates 2011

[2] R. Valerdi and R. J. Kohl, "An Approach to Technology Risk management," presented at Engineering Systems Division Symposium, MIT , Cambridge, MA, USA, March 29-31, 2004.

[3] J. C. Mankins, "Technology Readiness Levels," (White Paper) ,Advanced Concepts Office, Office of Space Access and Technology, NASA, April 6, 1995.

[4] European Association of Research and Technology Organisations (EARTO), "The TRL Scale as a Research \& Innovation."

[5] F. Paun, "Demand readiness Level (DRL), a new tool to hybridize Market Pull and Technology Push approaches.," presented at A NR-ERANET Workshop, Paris, France, Feb. 2011.

[6] B. J. Sauser, J.E.Ramirez-Marquez, H. Devanandham and D. DiMarzio, "A system maturity index for the systems engineering lifecycle," International Journal of Industrial and Systems Engineering, Vol. 3, No. 6, 2008, pp. 1-31.

[7] C. Jullien: "Considerations for an innovation readiness level" along with the "Technology and Manufacturing Readiness Level" indicators". IEA Committee on Energy Research and Technology - Modelling and Analyses in R\&D Priority Setting an Innovation KIC InnoEnergy meeting, Paris, France, April $23-24,2014$, pp. 2-25.

[8] The Israel Mobile and Communications Association, "IMA Launches an Innovation Lab in collaboration with Partner Communication," March 18, 2011, available online at http://www.imaworld.org/?CategorylD=187\&ArticleID=511\&print=1

[9] E. von Hippel, "Lead Users: A source of novel product concepts," Management Science, Vol. 32, No. 7, July 1986, pp. $791-805$

[10] G. S. Day, "The capabilities of market driven organizations," the Journal of Marketing, Vol. 58, 1994, pp. 37-52.

[11] S. Ram and J. N. Sheth, "Consumer resistance to innovations: The marketing problem and its solutions," The Journal of Consumer Marketing, Vol. 6, No. 2, 1989, pp. 5-14.

[12] F. Davis, "A technology acceptance model for empirically testing new end-user information systems - theory and results," PhD thesis, MIT, 1985.

[13] R. G. Fichner and C. F. Kemerer, "The illusory diffusion of innovation: An examination of assimilation gaps," Information Systems Research, Vol. 10, No.3, September 1999, pp. 255-275.

\section{References (2)}

[14] H. D. Leu; L. F. Hsu, C. Y. Yi and J. K. Shu, "The impacts of business model and marketing mix strategy on innovation adoption intention by consumer: Cases observation in Taiwan's $3 \mathrm{G}$ telecom carriers (2010), available online at http://baiconference.org/files/BAl2010\%20Proceeding/Marketing.htm.

[15] A. Witzel, "The problem-centered interview," Forum: Qualitative Social Research, Vol. 1, No. 1, available online at http://www.qualitativeresearch.net/index.php/fqs/article/viewArticle/1132

[16] D. F. Kocaoglu, "A participative approach to program evaluation," IEEE Transactions on Engineering Management, Vol. EM30, No. 3, Aug. 1983, pp. $112-118$

[17] T. L. Saaty, "What is the Analytical Hierarchy Process?" Mathematical Models for Decision Support, NATO ASI Series, Vol. 48, 1988, pp. 109-121.

[16] C. Carlsson and R. Fullér, "Fuzzy multiple criteria decision making: Recent developments," Fuzzy Sets and Systems, Vol. 78, No. 2, March 1996, pp. 139-153.

[18] R. Levine, C. Locke and D. Searls, Das Cluetrain Manifest: 95 Thesen für die neue Unternehmenskultur im digitalen Zeitalter, Econ Verlag, 2002, ISBN 3430159679.

[19] M. Biegl, R. Hasenauer, et al., "Marketing testbeds for high tech innovation: The case of Taurob Robotics," Proceedings of PICMET'14, Kanazawa, Japan, July 27 - 31, 2014, pp. 1145-1168.

[20] H. Jander, J. Borgvall and R. Ramberg, "Towards a methodological framework for HMI Readiness Evaluation," Proceedings of the Human Factors and Ergonomic Society, 56th Annual Meeting, Sept. 2012, Vol. 56, No. 1, pp. 2349-2354

[21] T. Lan, "Developing the Concept - Innovation Readiness Levels ," technical report , Center of Technology Management, Univ. of Cambridge, UK, 2010

[22] KTH Royal Institute of Technology, Stockholm: Innovation support system, 2012. 


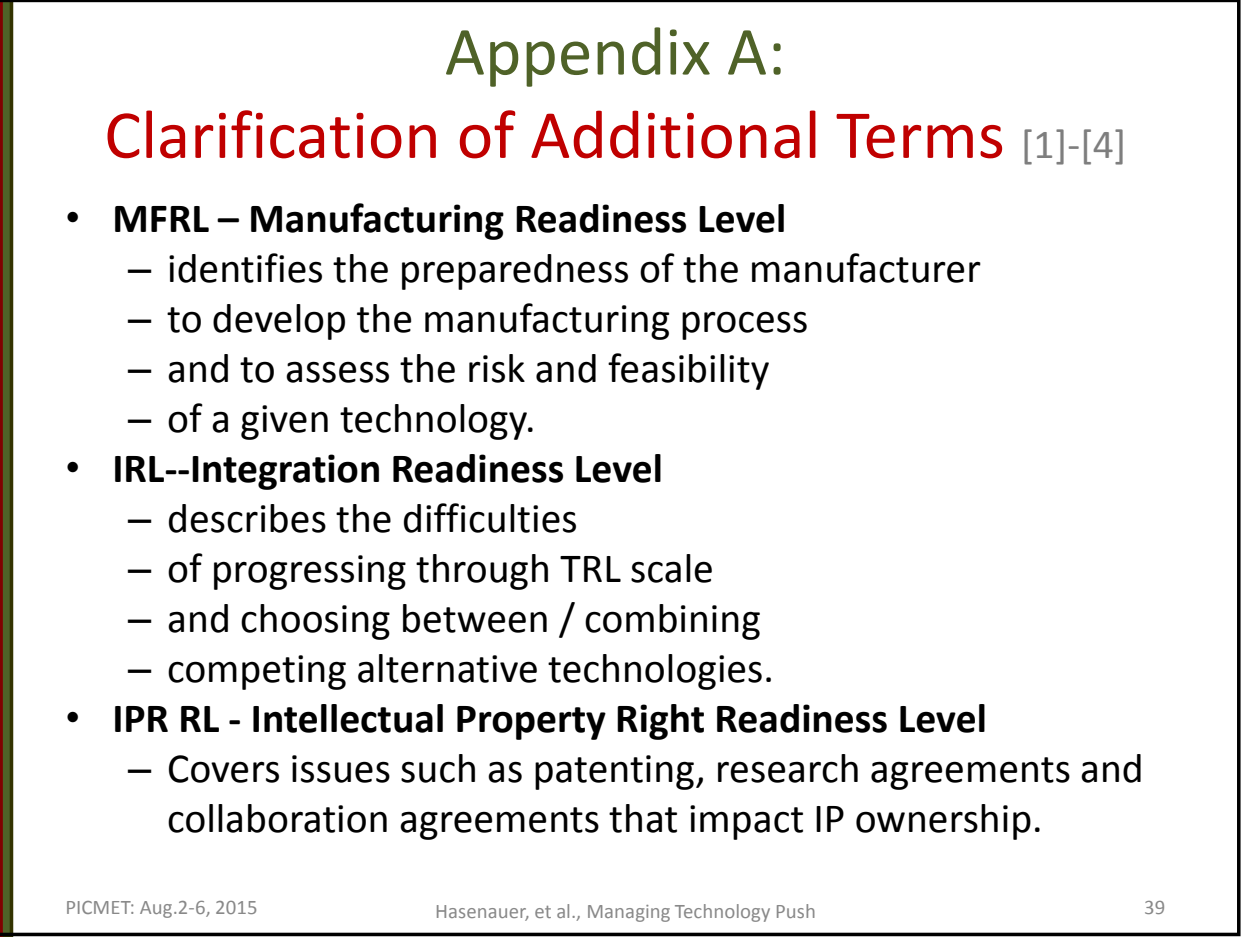

\section{Clarification of Additional Terms [1]-[4]}

MFRL - Manufacturing Readiness Level

- identifies the preparedness of the manufacturer

- to develop the manufacturing process

- and to assess the risk and feasibility

- of a given technology.

IRL--Integration Readiness Level

- describes the difficulties

- of progressing through TRL scale

- and choosing between / combining

- competing alternative technologies.

IPR RL - Intellectual Property Right Readiness Level

- Covers issues such as patenting, research agreements and collaboration agreements that impact IP ownership.

Readiness Levels

\section{APPENDIX B}




\section{Integration Readiness Levels}

\section{Level Action Performed}

$$
\text { [6], [20] }
$$

An Interface between technologies has been identified with sufficient detail to allow characterization of the relationship

2 There is some level of specificity to characterize the Interaction (i.e. ability to influence) between technologies through their interface.

3 There is compatibility (i.e. common language) between technologies to orderly and efficiently integrate and interact

4 There is sufficient detail in the quality and assurance of the integration between technologies.

$5 \quad$ There is sufficient control between technologies necessary to establish, manage, and terminate the integration

6 The integrating technologies can accept, translate, and structure information for its intended application.

$7 \quad$ The integration of technologies has been verified and validated with sufficient detail to be actionable.

8 Actual integration completed and mission qualified through test and demonstration, in the system environment.

9 Integration is mission proven through successful mission operations.

\section{Innovation Readiness Levels [21]}

- Innovation Readiness Level (IRL) expresses the readiness of an organization to implement and safely use an innovation by intended and educated user.

\section{Concept}

TRL 2 Technology concept and/or application formulated

TRL 3 Analytical and experimental critical function and/or characteristic proof-of-concept

TRL 4 Component and/or breadboard validation in laboratory environment

TRL 5 Component and/or breadboard validation in relevant environment

TRL 6 System/subsystem or prototype demonstration in a relevant environment (ground or space)

TRL 7 System prototype demonstration in a space environment

TRL 8 Actual system completed and "flight qualified" through test and demonstration

\section{Completion}

TRL 9 Actual system "flight proven" through successful mission operations 


\section{Intellectual Property Readiness Level [22]}

\section{Level Action performed}

$1 \quad$ Hypothesizing on possible IPR (patentable inventions)

2 Identified specific patentable inventions or other IPR

3 Detailed description of possible patentable inventions. Initial search of the technical field and prior art.

$4 \quad$ Confirmed novelty and patentability; decided on alternative IP protection if not patenting

5 First complete patent application filed, Draft of IPR strategy done.

6 Positive response on patent application; initial assessment of freedom to operate, patent strategy supporting business

7 Patent entry into national phase; other formal IPR registered

8 First patent granted, IPR strategy fully implemented, more complete assessment of freedom to operate

9 Patent granted in relevant countries, strong IPR support for business

\section{Marketing Testbeds}

Theoretical Foundation [19]

\section{APPENDIX C}




\section{Market Entry \& Window of Opportunity [8]}

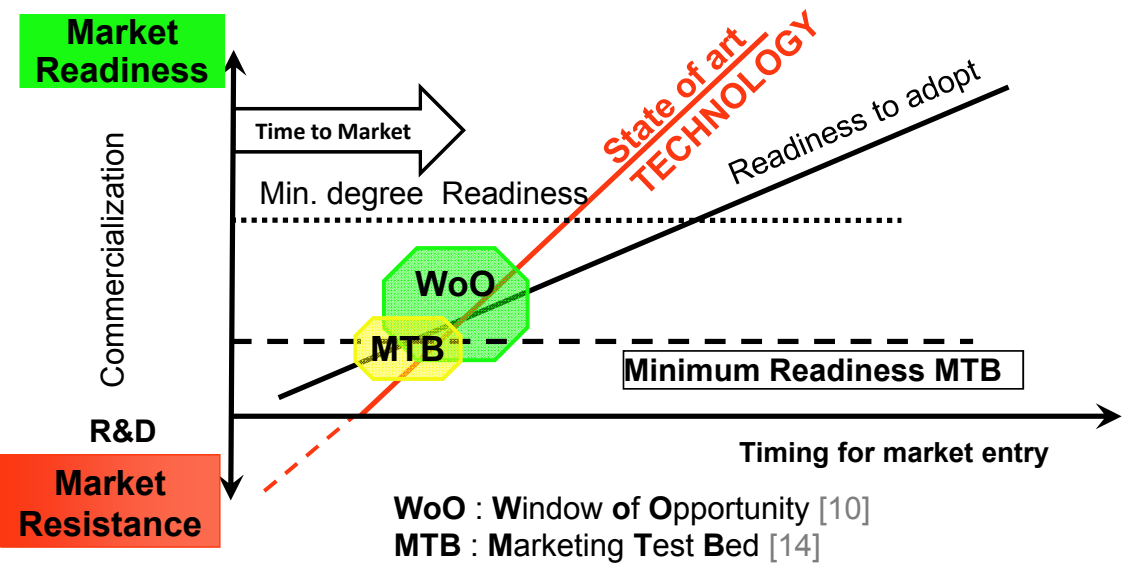

- Early on, fear of adoption - technology not quite ready; only lead users adopt

- MTB identifies and characterizes potential markets for a technology before window of opportunity opens.

- Reduces decision uncertainty; accelerates market entry speed

\section{Readiness and Resistance to Innovation}

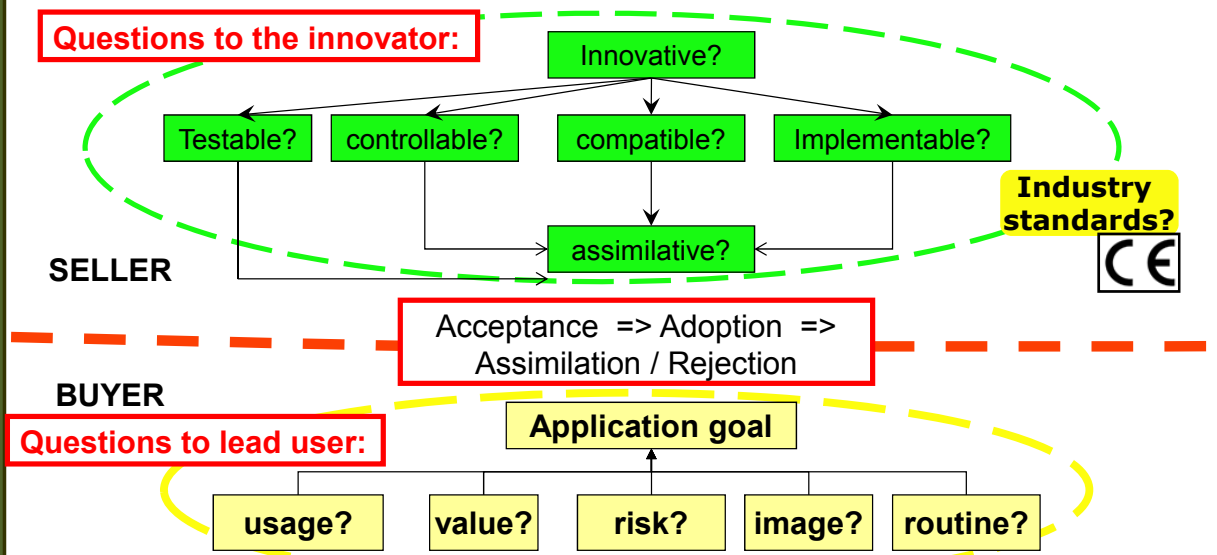

- MTB determines under which circumstances innovator's capabilities meet buyer's needs.

- MTB serves as a translator between seller's language and buyer's language

- Resistance to adoption of innovation drops as parties increase mutual understanding. 


\section{High Tech Innovation: Criteria for Acceptance and Marketability}

(C 1) Innovative?

(C 2) Testable/correctable?

(C 3) Controllable?

(C 4) Compatible?

(C 5) Implementable?

(C 6) Assimilative?

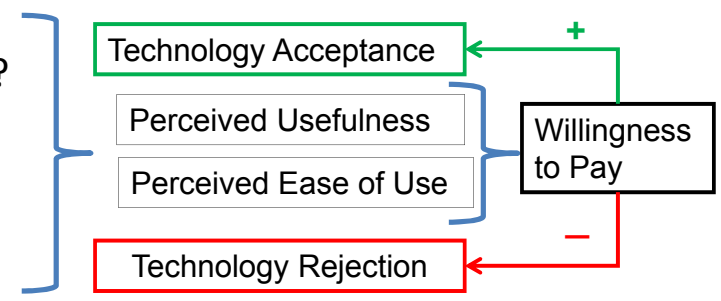

\section{Technology Acceptance:} An Iterative Process

TAM - Structural Equation Model [10]

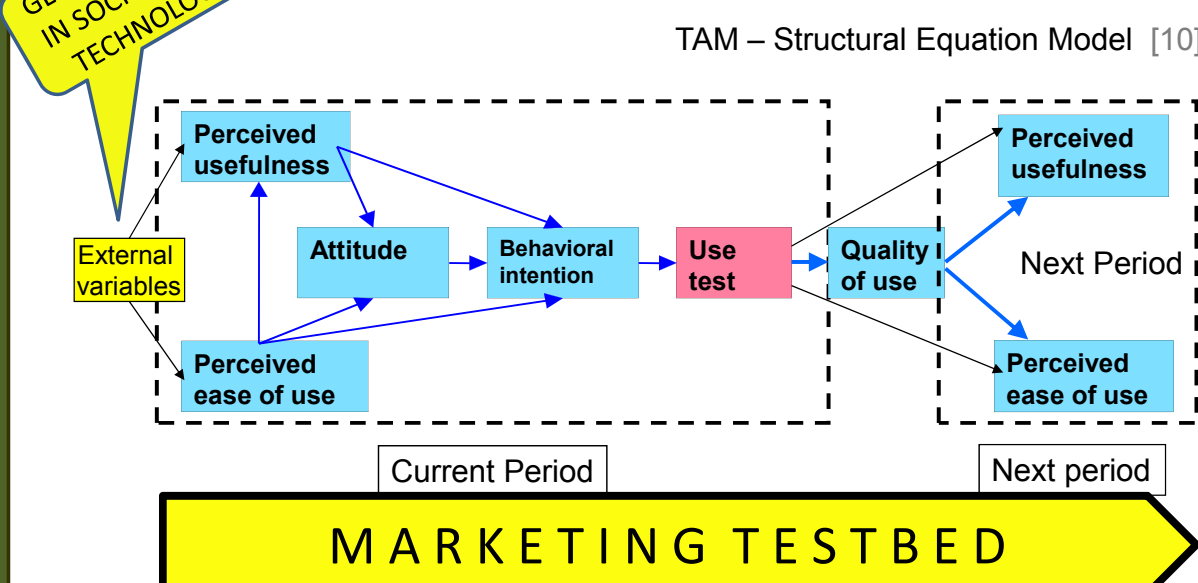




\section{High-Tech Innovation: Market Entry}

From latent demand via emerging demand to real demand

Latent demand: WISHES

Supply development accelerated by research cooperation

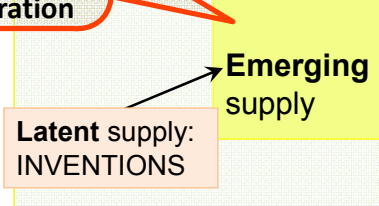

Time Arrow

past present Emerging demand

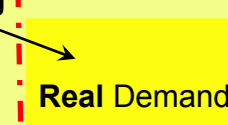
user-based prices.

High compliance with marketability criteria $\mathrm{C} 1$ through $\mathrm{C} 6$ increases price autonomy in the market segment.

future

- Lead users operate under emerging demand

- Mainstream users operate under real demand.

\section{MTB and Market Entry}

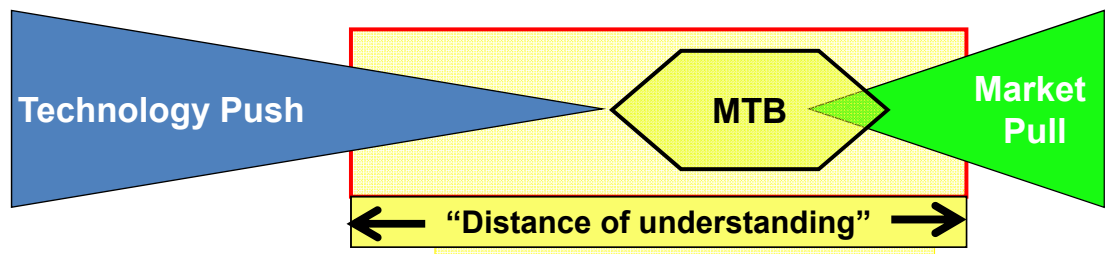

Innovator's

Ear

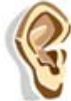

Markets are conversations.

Customer's Voice

- Markets are conversations [18] that occur in two different "content-languages".

- The MTB translates the language of the customer into the language of the innovator, and conversely.

- Reduces distance of understanding; shortens time to market.

- Customer offers come shortly after customer and developer understand each other 


\section{Iterative Marketing Testbed Process}

- Marketing mix = customization of 4Ps for specific market segment

- MTB determines content of marketing mix for each segment.

- Marketing mixes are integrated into marketing model

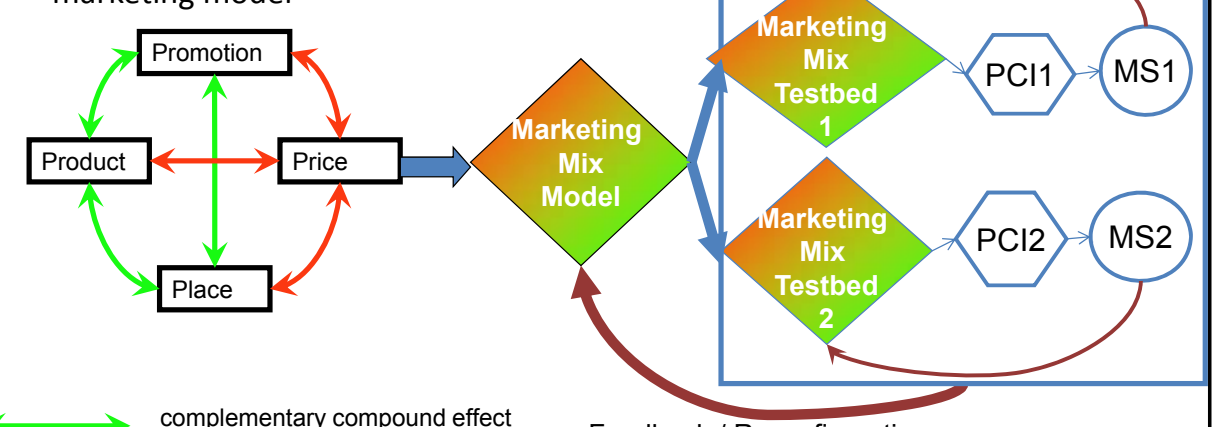

complementary compound effect substitutional compound effect

Feedback / Reconfiguration (cross elasticity)

PCI: Problem Centered Interviews MS: Market Segment

\section{Readiness Levels for 26 Projects}

\section{APPENDIX D}




\section{Material Science Innovation/Medical Devices}

\begin{tabular}{|c|c|c|c|c|c|c|c|c|c|c|c|c|}
\hline & & & & & & TECHNO & LOGY & & & & ARKET & \\
\hline Id & Innovation & year & industry & \begin{tabular}{|l} 
Intellect \\
Prop. \\
Right- RL
\end{tabular} & $\begin{array}{l}\text { Technol } \\
\text { ogy-RL }\end{array}$ & \begin{tabular}{|l} 
Integra \\
ion RL
\end{tabular} & $\begin{array}{l}\text { Manu- } \\
\text { fact RL }\end{array}$ & MEAN & $\begin{array}{l}\text { Demand } \\
\text { RL }\end{array}$ & \begin{tabular}{|c|} 
Custo- \\
mer RL
\end{tabular} & $\begin{array}{l}\text { Product } \\
\text { RL }\end{array}$ & MEAN \\
\hline 1 & $\begin{array}{l}\text { atmospheric plasma for } \\
\text { wood surface energy }\end{array}$ & 2013 & $\begin{array}{l}\text { material } \\
\text { science }\end{array}$ & 2 & 3 & 2 & 2 & 2 & 2 & 3 & 2 & 2 \\
\hline K & flame retardant rubber & 2013 & $\begin{array}{l}\text { material } \\
\text { science }\end{array}$ & 8 & 8 & 6 & 8 & 8 & 9 & 8 & 8 & 8 \\
\hline M & bone diagnostics & 2013 & $\begin{array}{l}\text { medical } \\
\text { diagnosis }\end{array}$ & 6 & 6 & 5 & 5 & 6 & 8 & 6 & 4 & 6 \\
\hline $\mathrm{N}$ & $\begin{array}{l}\text { Continuous Non-Invasive } \\
\text { Blood-Pressure }\end{array}$ & 2012 & $\begin{array}{l}\text { medical } \\
\text { diagnosis }\end{array}$ & 8 & 6 & 6 & 5 & 6 & 5 & 5 & 2 & 4 \\
\hline $\mathrm{s}$ & $\begin{array}{l}\text { vibrational acoustic } \\
\text { analysis }\end{array}$ & 2012 & $\begin{array}{l}\begin{array}{l}\text { medical } \\
\text { diagnosis }\end{array} \\
\end{array}$ & 3 & 3 & 3 & 2 & 3 & 4 & 4 & 2 & 3 \\
\hline W & bionic surface & 2011 & $\begin{array}{l}\text { material } \\
\text { science }\end{array}$ & 2 & 3 & 2 & 2 & 2 & 4 & 4 & 3 & 4 \\
\hline $\mathrm{x}$ & cellular materials & 2011 & $\begin{array}{l}\begin{array}{l}\text { material } \\
\text { science }\end{array} \\
\end{array}$ & 4 & 4 & 3 & 5 & 4 & 4 & 3 & 3 & 3 \\
\hline z & diamond like carbon & 2011 & $\begin{array}{l}\begin{array}{l}\text { material } \\
\text { science }\end{array} \\
\end{array}$ & 3 & 4 & 4 & 4 & 4 & 6 & 4 & 5 & 5 \\
\hline
\end{tabular}

\section{Robotics \& Sensors}

\begin{tabular}{|c|c|c|c|c|c|c|c|c|c|c|c|c|c|c|}
\hline \multirow[b]{2}{*}{ Id } & \multirow[b]{2}{*}{ Innovation } & \multirow[b]{2}{*}{ year } & \multirow[b]{2}{*}{ industry } & \multicolumn{6}{|c|}{ TECHNOLOGY } & \multicolumn{5}{|c|}{ MARKET } \\
\hline & & & & \begin{tabular}{|l|l|} 
Intellect & Te \\
Prop. & olc \\
Right- RL & RL
\end{tabular} & $\begin{array}{l}\text { Techn } \\
\text { ology- } \\
\text { RL }\end{array}$ & $\begin{array}{l}\text { Integr } \\
\text { ation } \\
\text { RL }\end{array}$ & $\begin{array}{l}\text { Manu- } \\
\text { fact RL }\end{array}$ & SUM & MEAN & \begin{tabular}{|l|} 
Demand \\
RL
\end{tabular} & \begin{tabular}{|l} 
Custo- \\
mer \\
RL
\end{tabular} & $\begin{array}{l}\mathrm{P}-\text { Product } \\
\text { RL }\end{array}$ & SUM & MEAN \\
\hline C & $\begin{array}{l}\text { atmospheric nitrogen } \\
\text { deposition collector } \\
\text { device }\end{array}$ & 2014 & sensor & 3 & 6 & 4 & 6 & 19 & 5 & 4 & 3 & 3 & 10 & 3 \\
\hline $\mathrm{F}$ & $\begin{array}{l}\text { New sensors for mobile } \\
\text { robots }\end{array}$ & 2014 & sensor & 3 & 4 & 3 & 5 & 15 & 4 & 4 & 4 & 3 & 11 & 4 \\
\hline G & Health CCPM & 2013 & robotics & 8 & 6 & 5 & 6 & 25 & 6 & 4 & 4 & 2 & 10 & 3 \\
\hline $\mathrm{H}$ & Safety Robot & 2013 & robotics & 8 & 9 & 8 & 7 & 32 & 8 & 9 & 8 & 9 & 26 & 9 \\
\hline V & $\begin{array}{l}\text { mmi pressure and } \\
\text { temperature sensors }\end{array}$ & 2011 & sensor & 4 & 5 & 3 & 5 & 17 & 4 & 5 & 4 & 3 & 12 & 4 \\
\hline
\end{tabular}




\section{Software, Sensor \& 3D Printing}

\begin{tabular}{|c|c|c|c|c|c|c|c|c|c|c|c|c|c|c|}
\hline & & & & \multicolumn{6}{|c|}{ TECHNOLOGY } & \multicolumn{5}{|c|}{ MARKET } \\
\hline & Innovation & year & industry & $\begin{array}{l}\text { Intellect } \\
\text { Prop. } \\
\text { Right- RL }\end{array}$ & $\begin{array}{l}\text { Techn } \\
\text { ology- } \\
\text { RL }\end{array}$ & $\begin{array}{l}\text { Integr } \\
\text { ation } \\
\text { RL }\end{array}$ & $\begin{array}{l}\text { Manu- } \\
\text { fact RL }\end{array}$ & SUM & MEAN & $\begin{array}{l}\text { Demand } \\
\text { RL }\end{array}$ & $\begin{array}{l}\text { Custo- } \\
\text { mer } \\
\text { RL }\end{array}$ & $\begin{array}{l}\text { Product } \\
\text { RL }\end{array}$ & SUM & MEAN \\
\hline B & technical simulation & 2014 & software & 3 & 8 & 6 & 7 & 24 & 6 & 9 & 8 & 8 & 25 & 8 \\
\hline c & $\begin{array}{l}\text { atmospheric nitrogene } \\
\text { deposition collector } \\
\text { device }\end{array}$ & 2014 & sensor & 3 & 6 & 4 & 6 & 19 & 5 & 4 & 3 & 3 & 10 & 3 \\
\hline D & Aerosoljet-printing & 2014 & 3d printing & 9 & 6 & 4 & 8 & 27 & 7 & 4 & 3 & 2 & 9 & 3 \\
\hline E & Selective Laser Melting & 2014 & $3 d$ printing & 9 & 6 & 6 & 8 & 29 & 7 & 4 & 3 & 4 & 11 & 4 \\
\hline $\mathrm{F}$ & $\begin{array}{l}\text { New sensors for mobile } \\
\text { robots }\end{array}$ & 2014 & sensor & 3 & 4 & 3 & 5 & 15 & 4 & 4 & 4 & 3 & 11 & 4 \\
\hline $\mathrm{L}$ & $\begin{array}{l}\text { Magic Lens augmented } \\
\text { reality }\end{array}$ & 2013 & software & 2 & 8 & 6 & 8 & 24 & 6 & 9 & 9 & 9 & 27 & 9 \\
\hline 0 & $\begin{array}{l}\text { watch dog for } \\
\text { semiconductor }\end{array}$ & 2012 & software & 3 & 6 & 5 & 7 & 21 & 5 & 7 & 6 & 5 & 18 & 6 \\
\hline $\mathrm{R}$ & lab on chip diagnostics & 2012 & software & 8 & 4 & 3 & 4 & 19 & 5 & 5 & 5 & 2 & 12 & 4 \\
\hline v & $\begin{array}{l}\text { mmi pressure and } \\
\text { temperature sensors }\end{array}$ & 2011 & sensor & 4 & 5 & 3 & 5 & 17 & 4 & 5 & 4 & 3 & 12 & 4 \\
\hline
\end{tabular}

